\title{
Molecular detection of ALS1 virulence gene of Candida albicans isolated from groups of Iraqi patients
}

\author{
Aysha Saber Ali* \\ Azhar A.F. Al-Attraqhchi* \\ Saife D. Al-Ahmar**
}

\author{
Vet. ,MSc (Micro) \\ BSc, MSc, PhD (Mycology) \\ BSc, MSc, PhD (Engeneering and technology)
}

\begin{abstract}
:
Background: Candida albicans is the principal fungal infectious agent in human infection. Adhesion is thought to be an essential step for colonization and establishment of Candida infections.

Objectives: Identification and comparison of ALS1 virulence gene of adhesion family among different isolates of Candida albicans by PCR.

Patients and methods: One hundred eight samples were collected from different group of Iraqi patients.

Fac Med Baghdad 2015; Vol.57, No.1 Received: Oct.,2014 Accepted: Feb.,2015 All samples were culture on Sabouraud's agar, CHROMagar for identification while API Candida kit confirmatory test and extracted DNA was done for just Candida albicans isolates, detected the ALS1 gene, extracted RNA for synthesis of cDNA and detected of gene and compare between isolates.

Result: C. albians isolated from each of vaginal and oral swabs expressed the stronger gene that mean these isolates were the most virulent once. The two isolates from each of urine sample and nail clip which expressed only one strong fluorescence represented by ALS1 gene. C. albicans isolated from cutaneous scrap sample showed the only one moderate fluorescence represented by ALS1 gene.

Conclusion: C. albians isolated from each of vaginal and oral swabs expressed the stronger gene that's mean these isolates were the most virulent once.

Key words: Candida albicans, ALS1 gene, PCR virulence gene.
\end{abstract}

\section{Introduction:}

Superficial infections of skin and mucous membranes are the most common types of candidal infections of the skin. (1) Cutaneous candidiasis is an opportunistic infection that arises, in most cases, from endogenous, saprophytic Candida blastospores that selectively colonize oral, gastrointestinal, vaginal, and cutaneous epithelium. $(2,3)$

Being a commensal, Candida albicans is expected to inhabit the urogenital and gastrointestinal tract of a large percentage of the human population. In healthy individuals, its growth is confined by actions of the immune system and by the presence of other commensal microorganisms occupying its potential niche. However, when any one of these barriers is disrupted, C. albicans can behave as a pathogen causing both superficial and systemic infections, the latter with possible infections of internal organs. $(4,5)$

C. albicans has a specialized set of proteins (adhesins) which mediate adherence to other $\mathrm{C}$. albicans cells to other microorganisms, to abiotic surfaces and to host cells. $(6,7)$ Arguably the best studied C. albicans adhesions are the agglutinin-like sequence (ALS) proteins which form a family consisting of eight members (Als1-7 and Als9). The ALS genes encode glycosylphosphatidylinositol (GPI)-linked cell

*Dept. of Microbiology, College of Medicine/Al-Nahrain University e-mail of correspondence*:aysha.2005@yahoo.com

**Genetic Engeneering Institute/University of Baghdad. surface glycoproteins. Of the eight Als proteins, the hypha associated adhesin Als3 is especially important for adhesion (8-10). ALS1 gene expression is upregulated during infection of oral epithelial cells in vitro and during in vivo vaginal infection. (11-14)

Chromogenic media have shown better detection rates of yeasts in mixed cultures than traditional media and allow direct and more rapid identification of Candida albicans and also other species. $(15,16)$

Detection of Candida on CHROMagar Candida from poly fungal specimen also allows direct and more rapid and specific identification of C. albicans and other spp. (17)

These systems offer the potential for more rapid and specific identification of Candida spp. Co

mpared to traditional phenotypic methods. Most nucleic acidbased systems use polymerase chain reaction (PCR) techniques to amplify fungal DNA as the first step in the identification process. Before PCR amplification can occur, appropriate DNA targets extraction and PCR primers must be selected. $(18,19)$.

\section{Materials and Patients:}

One hundred eight samples were collected from different group of Iraqi patients in Medical Imammian kadhamain city, National center of Hematology, National diabetic center and Al-Forat hospital and private Iraq clinic. Thirty six oral swab 
were taken from patients who were diagnosed with leukemia, twenty five vaginal swab were taken from pregnant women, twenty five urine sample were taken from diabetic patients and twelve cutaneous swab and ten nail clipping sample were collected from patients. All swabs and urine were cultured on Sabouraud's Dextrose Agar and incubated at $37 \mathrm{C}^{\circ}$ for 48 hours. All swabs and urine were cultured on CHROMagar (Biomuriex) for 48 hours at $37^{\circ} \mathrm{C}$. The production of colour and morphology as described by the manufacturer were recorded and the photographs were recorded. The confirmatory test for Candida albicans was done by API Candida kit (Biomuriex). Samples tubes were mixed thoroughly, and then DNA was extracted from each sample by using Wizard Genomic DNA purification kit (Promega, USA). The PCR using high fidelity DNA polymerase was adopted to identify the agglutinin-like sequence 1 (ALS1) gene in the DNA sample of Candida albicans. Samples tubes were mixed thoroughly, and then RNA was extracted from each sample by using Wizard Genomic RNA purification kit (Promega, USA). RNA isolated were converted in to the first strand cDNA from each sample by using Wizard Go Scrpit ${ }^{\mathrm{TM}}$ Reverse Transcriptase kit (Promega, USA). The agglutinin-like sequence 1 (ALS1) gene of Candida albicans using PCR was performed.

\section{Results:}

\section{Identification of Candida albicans:}

Culture on Sabouraud's Dextrose Agar: All swabs and urine sample were cultured on Sabouraud's Dextrose agar, the result showed fifty seven white

creamy colonies which were twenty three from oral

swab, fifteen from vaginal swab, ten urine sample, six from cutaneous scrap and three nail clip samples.

CHROMagar culture: All white creamy colonies were grew on Sabouraud's Dextrose Agar were subculture on CHROM agar media to identify of Candida albicans. A Total number twenty five of blue colonies represented Candida albicans were obtained as nine isolated from vaginal swabs, eight from oral swab, four from urine sample, three from cutaneous scrap and one from nail clip samples. Figure (1)

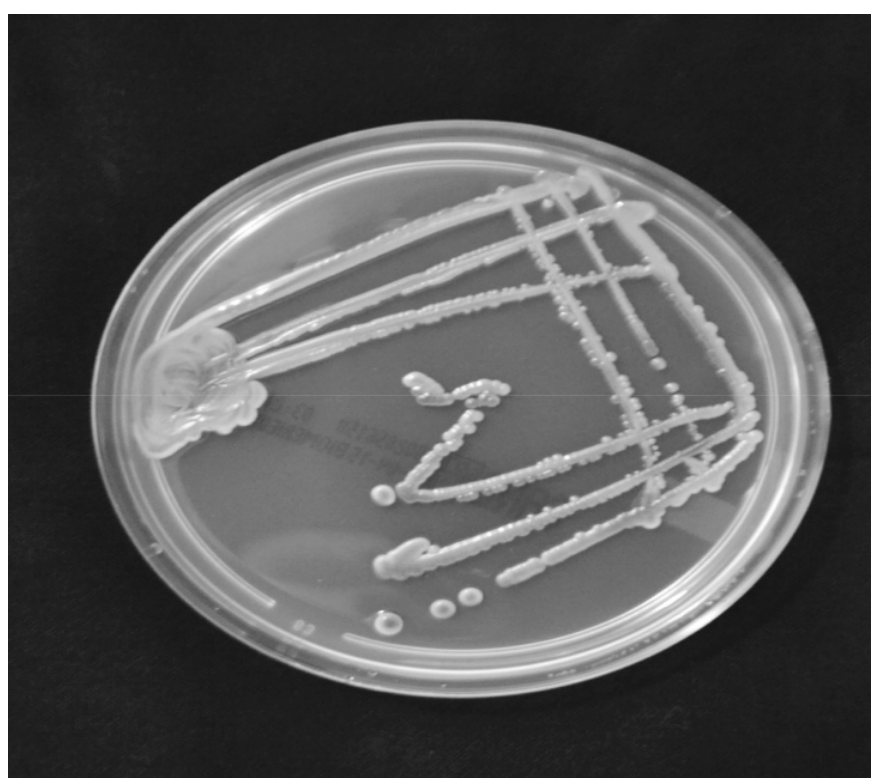

Figure (1): Blue Colonies of Candida albicans on Chrom Agar.

API Candida kit for confirming:Candida albicans isolates were re identified by biochemical API Candida, the results coordinated those of CHROM agar media.

Extraction of Candida albicans DNA: Twenty five samples which were positive in API Candida were extracted by using Wizard ${ }^{\circledR}$ Genomic DNA purification kit (Promega, USA). Figure (2).

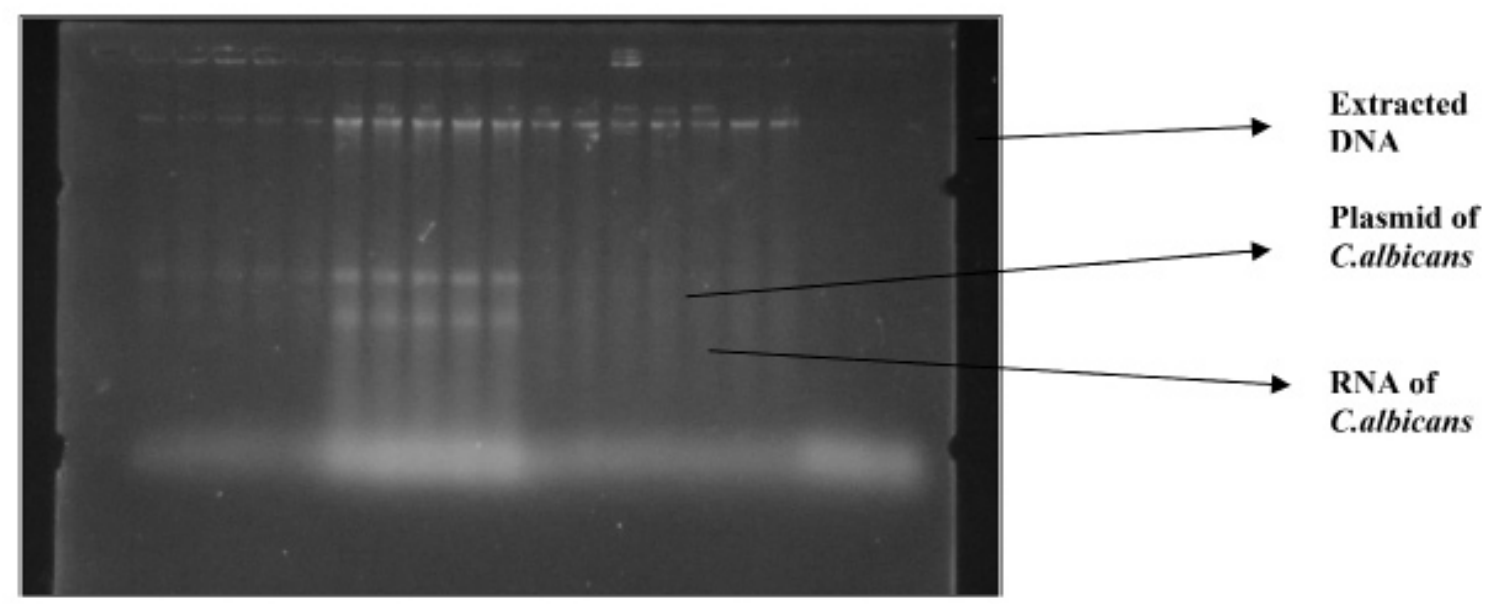

(Figure 2): Gel electrophoresis of extracted DNA from Candida albicans isolates on 1\% agarose gel at $7 \mathrm{volt} / \mathrm{cm}$ for 1 hour. 
Out of 25 Candida albicans isolates, nine were isolated from vaginal swabs, eight from oral swab, four from urine sample, three from cutaneous scraps and only one from nail clip sample. Table (1)

Table (1): Candida albicans isolates according to the type of sample.

\begin{tabular}{ccc}
\hline Samples & No. of samples & $\begin{array}{c}\text { No. of Candida } \\
\text { albicans }\end{array}$ \\
\hline Oral swabs & 23 & 8 \\
\hline Vaginal swabs & 15 & 9 \\
\hline Urine samples & 10 & 4 \\
\hline Cutaneous scrap & 6 & 3 \\
\hline Nail clips & 3 & 1 \\
\hline All & 57 & 25 \\
\hline
\end{tabular}

Detection of agglutinin-like sequence 1 (ALS1) gene using PCR: Twelve out of twenty five isolates of Candida albicans were positive for ALS1 gene. PCR product of this gene was 318 bp. Figure (3)

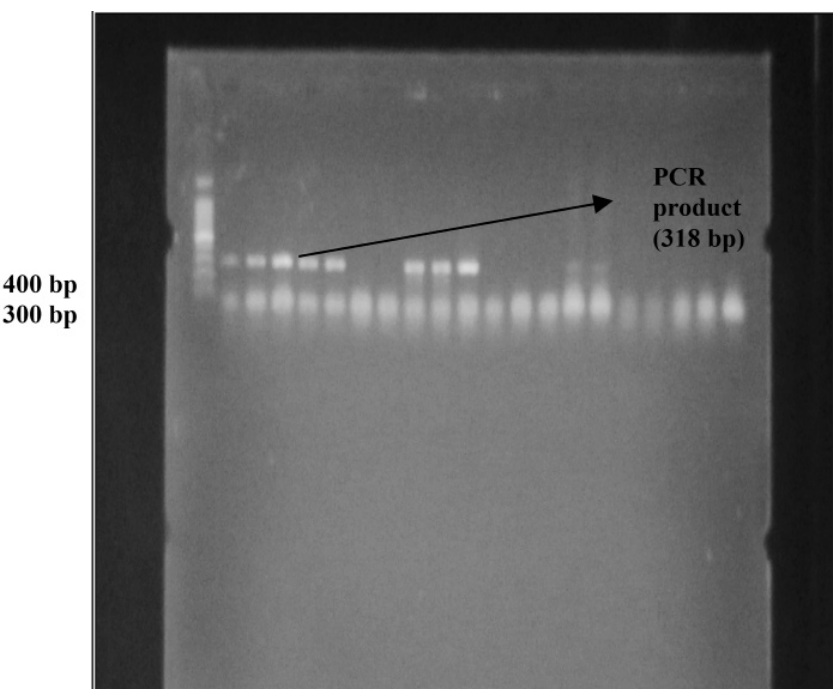

Figure (3): Gel electrophoresis of singleplex PCR products of als1 gene of Candida albicans on $1 \%$ agarose gel at 7 volt /cm for 1 hour. Lane 1: 100bp DNA ladder.

Among those eight isolates of C.albicans from oral swabs, only seven were positive for ALS1gene (87.5\%); vaginal swabs, only one $(11.11 \%)$ out of nine isolates was positive; In urine samples isolates $(50 \%)$, two isolates out of four were positive; One isolate out $(33.33 \%)$ of three from cutaneous scrap and another (100\%)from nail clip sample were positive for this gene. Table(2).
Table (2): ALS1 gene in Candida albicans concerning type of sample.

\begin{tabular}{ccccc}
\hline Samples & $\begin{array}{c}\text { NO. of } \\
\text { samples }\end{array}$ & $\begin{array}{c}\text { No. of } \\
\text { fungal } \\
\text { growth }\end{array}$ & $\begin{array}{c}\text { No. of } \\
\text { Candida } \\
\text { albicans }\end{array}$ & $\begin{array}{c}\text { NO. of } \\
\text { ALS1 }\end{array}$ \\
\hline Oral swabs & 36 & 23 & 8 & $7(87.5 \%)$ \\
\hline $\begin{array}{c}\text { Vaginal } \\
\text { swabs }\end{array}$ & 25 & 15 & 9 & $1(11.11 \%)$ \\
\hline $\begin{array}{c}\text { Urine } \\
\text { samples }\end{array}$ & 25 & 10 & 4 & $2(50 \%)$ \\
\hline $\begin{array}{c}\text { Cutaneous } \\
\text { scrap }\end{array}$ & 12 & 6 & 3 & $1(33.33 \%)$ \\
\hline Nail clips & 10 & 3 & 1 & $1(100 \%)$ \\
\hline All & 108 & 57 & 25 & $12(48 \%)$ \\
\hline
\end{tabular}

Extraction of Candida albicans RNA: Among twenty five isolates, eight samples which were positive for ALS1 gene were under went by RNA Isolation and purification of SV Total RNA Isolation System kit (Promega, USA). Eight samples of RNA showed positive results for ALS1 gene were converted to cDNA for detection density of the genes by using GoScriptn ${ }^{\mathrm{TM}}$ Reverse Transcriptase kit (Promega, USA). PCR product of cDNA of ALS1 (318) bp were showed Varity in fluorescence of density on agarose gel. Figure (4)

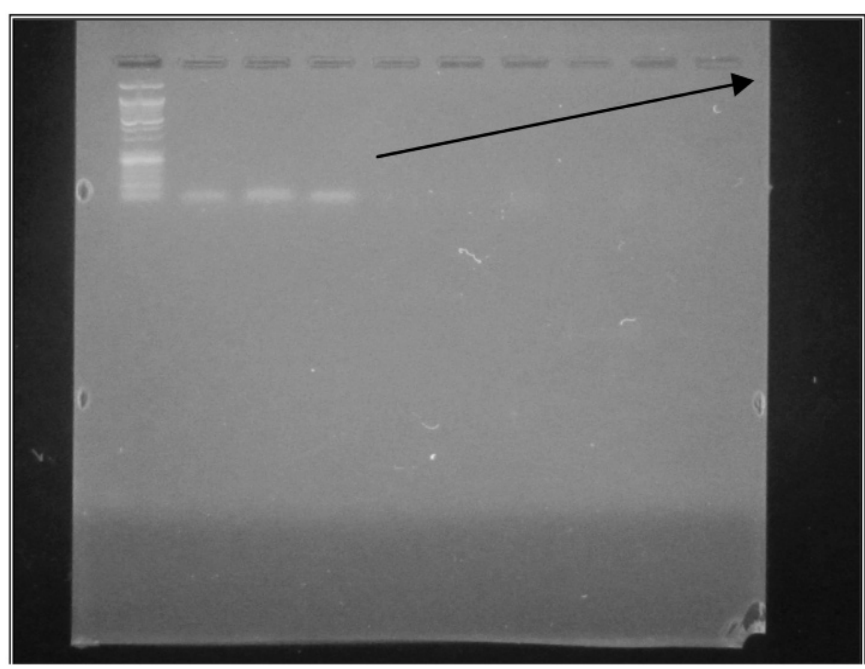

Figure (4): Gel electrophoresis of single PCR products of als1 genes of Candida albicans on $1 \%$ agarose gel at $7 \mathrm{volt}$ / cm for 30 minutes. Lane 1: 100bp DNA ladder

Concerning PCR product of cDNA, eight isolates of C. albicans as three from oral swabs, only one from vaginal swabs, two urine samples isolates; One isolate out of three from cutaneous scrap and another from nail clip sample showed different degree of florescence under U.V light in gel electrophoresis . 


\section{Discussion:}

In this study, it has been found that all Candida albicans isolates reveals the presence of ALS1gene, represented as $87.5 \%$ from oral swabs, $11.11 \%$ from vaginal swabs, $50 \%$ from urine samples, $33.33 \%$ from cutaneous scrap and $100 \%$ from nail clips. According to the study done by Inci, M. et. al. (20) who found that ALS1gene was present in all samples included in the study represented as $48.0 \%$ from vaginal swabs, $84.6 \%$ from oral swabs and $52.4 \%$ from urine samples. These results agree with those included in this study, concerning the gene content of Candida albicans isolated from oral swabs and urine samples and disagreement regarding those isolated from vaginal swabs this may due to the differences in the number of samples enrolled in this study or the method of diagnosis. Green et. al. (21) evaluated the expression patterns of genes in the ALS gene family in clinical oral, vaginal and urine specimens by reverse transcriptase-PCR (RT-PCR). They showed that the ALS1 gene was expressed at all time points and inoculation densities. Moreover, they reported that gene expression patterns were found to be similar in the clinical strains of these samples. Expression of ALS1 genes was evaluated in both clinical samples and vaginal candidiasis models by using the RT-PCR method in another study. ALS1, were reported as the most commonly expressed genes of the ALS gene family and, in the same study, similar expression frequencies and patterns were reported on clinical samples and model systems. Nas et. al. (22) investigated the expression of ALS1 gene in vaginal swab, oral swabs and urine samples by using the RT-PCR method. They found that the ALS1 gene was expressed in $70 \%, 75 \%$, and $67 \%$ of isolated Candida albicans from these samples, respectively. In this study, it was found that ALS1 was identified in eight different samples including three oral swab, one vaginal, one cutaneous, two urine and only one nail clip. Concerning the presence of AlS1 gene in C. albicans isolates from oral swabs, detected by PCR, it was found that seven out of eight isolates $(87.5 \%)$ were containing this gene, in the case of cDNA which was expressed as a fluorescence band by ultra violate in gel electrophoresis for three C. albicans isolates from oral swabs which expressed both genes, one was moderate and two were strong. Concerning the presence of AlS1 gene in C. albicans isolates from urine samples, detected by PCR, it was found that 2 out of 4 isolates $(50 \%)$ were containing this gene, in the case of cDNA which was expressed as a fluorescence band by ultra violate in gel electrophoresis for two C. albicans isolates from urine samples which expressed both genes, one was strong and the other was weak. Regarding the presence of AlS1 gene in C. albicans isolates from vaginal swabs, detected by PCR, it was found that 1 out of 9 isolates $(11.11 \%)$ were containing this gene, in the case of cDNA which was expressed as a fluorescence band by ultra violate in gel electrophoresis for this isolate from vaginal swabs which expressed both genes, it was strong. In the case of the presence of AlS1 gene in C. albicans isolates from cutaneous scraping, detected by PCR, it was found that 1 out of 3 isolates $(33.33 \%)$ were containing this gene, in the case of cDNA which was expressed as a fluorescence band by ultra violate in gel electrophoresis for this isolate from cutaneous scrap which expressed both genes, it was moderate. Finally, In the case of the presence of AlS1 gene in C. albicans isolates from nail clip sample, detected by PCR, it was found that 1 out of 1 isolates $(100 \%)$ were containing this gene, in the case of cDNA which was expressed as a fluorescence band by ultra violate in gel electrophoresis for this isolate from nail clip which expressed both genes, it was strong. These difference in the results of the current study and those obtained by Nas et., al may come from the differences in sample groups and the methods used for diagnosis and may due to the differences in the number of the samples.(22) From this study it has been found that C. albians isolated from each of vaginal and oral swabs expressed the stronger both genes that mean these isolates were the most virulent once, followed by two isolates from each of urine sample and nail clip which expressed only one strong fluorescence represented by ALS1 gene. While in the case of C. albicans isolated from cutaneous scrap sample showed the only one moderate fluorescence represented by ALS1 gene.

\section{Author contributions:}

Aysha Saber Ali/ master student ( Microbiology )

Prof. Dr. Azhar A.F. Al-Attraqhchi/ supervisor

Lecturer Dr. Saife Dawood Al-Ahmar/ co advisor

\section{References:}

1- A. Raz-Pasteur,Y. Ullmann, and I. Berdicevsky. The Pathogenesis of Candida Infections in a Human Skin Model: Scanning Electron Microscope Observations. ISRN Dermatology.2011, vol.pp.6.

2- T. M. Arendorf and D. M. Walker. "The prevalence and intraoral distribution of Candida albicans in man," Archives of Oral Biology, (1980) vol. 25, no. 1, pp. 1-10.

3- T. L. Ray and K. D. Wuepper, "Experimental cutaneous candidiasis in rodents. II. Role of the stratum corneum barrier and serum complement as a mediator of a protective inflammatory response," Archives of Dermatology, (1978). vol. 114, no. 4, pp. 539-543.

4- J. Berman and P. Sudbery, Candida albicans: a molecular revolution built on lessons from budding yeast, Nat Rev Genet, vol. 3, pp.918-930, 2002.

5. J. Kim and P. Sudbery, Candida albicans, a major human fungal pathogen. J Microbiol, (2011). vol. 49, pp.171-177.

6. M. Garcia, J. Lee, C. Ramsook, D. Alsteens, Y. Dufrêne and P. Lipke, A role for amyloid in cell aggregation and biofilm 
formation., PLoS One (2011); 6:e17632.

7. K. Verstrepen and F. Klis, adhesion and biofilm formation in yeasts, Mol Microbiol, (2006), vol. 60, pp. 5-15.

8. R. Zordan and B. Cormack, Adhesins on Opportunistic Fungal Pathogens. In: Calderone RA, Clancy CJ, ed. Candida and Candidiasis: (2012), ASM Press, Washington, DC, pp 243-259.

9. Q. Phan, C. Myers, Y. Fu, D. Sheppard, M. Yeaman and W. Welch, Als3 is a Candida albicans invasion that binds to cadherins and induces endocytosis by host cells, (2007), PLoS Biol, 5:e64.

10. C. Murciano, D. Moyes, M. Runglall, P. Tobouti, A. Islam and L. Hoyer, Evaluation of the role of Candida albicans agglutinin-like sequence (Als) proteins in human oral epithelial cell interactions, (2012), PLoS One, 7:e33362.

11. B. Wchtler, D. Wilson, K. Haedicke, F. Dalle and B. Hube, From attachment to damage: defined genes of Candida albicans mediate adhesion, invasion and damage during interaction with oral epithelial cells. PLoS One (2011); 6:e17046.

12. K. Zakikhany, J. Naglik, A. Schmidt-Westhausen, G. Holland, M. Schaller and B. Hube, In vivo transcript profiling of Candida albicans identifies a gene essential for interepithelial dissemination. Cell Microbiol (2007); 9:2938-54.

13. J. Naglik, D. Moyes, B. Wchtler and B. Hube . Candida albicans interactions with epithelial cells and mucosal immunity. Microbes Infect (2011); 13:963-76.

14. G. Cheng, K. Wozniak, M. Wallig, P. Fidel, S. Trupin and L. Hoyer, Comparison between Candida albicans agglutininlike sequence gene expression patterns in human clinical specimens and models of vaginal candidiasis. Infect Immun. (2005); 73:1656- 63.

15-A. Freydie 're, R. Guinet, and P. Boiron. Yeast identification in the clinical microbiology laboratory: phenotypical methods. Med. Mycol. (2001). 39:9- 33.

16- A. Freydie re, F. Parant, C. Chaux, and Y. Gille. Candida ID, a new chromogenic medium compared to Albicans ID2. Clin. Microbiol. Infect. (2000). 6(Suppl.1):181.

17. I. Schuffenecker, A. Freydiere, H. de Montclos , Y. Gille Y. Evaluation of four commercial systems for identification of medically important yeasts. Eur J Clin Microbiol Infect Dis. (1993); 12: 255_60.

18- S. Fujita, B.A. Lasker, T.J. Lott, E. Reiss, and C.J. Morrison. Microtitration plate enzyme immunoassay to detect PCR-amplified DNA from Candida species in blood. J Clin. Microbiol. (1995).33, 962-967.

19- C. Coignard, S. Hurst, L. Benjamin, M. Brandt, D. Warnock, and C. Morrison. Resolution of discrepant results for Candida species identification by using DNA probes. $J$ Clin. Microbiol. (2004). 42, 858-861.

20. M. Inci, A. Mustafa, Z. Burçin, E. Omer, D. Nizami, M. Vicdan, K. Ayşe, O. Yüsüf, K. Cetin, D. Süleyman .
Investigations of ALS1 and HWP1 genes in clinical isolates of Candida albicans. Turk J Med Sci. (2013). 43: 125-130.[ ivsl]

21. G. Green, G. Cheng, J. Chandra, P. Ghannoum, L. Hoyer. RT-PCR Detection of Candida albicans ALS gene expression in the reconstituted human epithelium (RHE) model of oral candidiasis in a model biofilm. Microbiology. (2004). 150, 267-275.[ivsl, highwire]

22. T. Nas, A. kalakanci, I. Fidan, K. Hizel, S. Bolat, S. Yolbakan, E. Yilmaz. Expression of ALS1, HWP1, and SAP4 Genes in Candida albicans Strain Isolated from Women with Vaginitis. Folia microbial. 2008. 53(2). 179-183. 